\title{
Health and Safety Disclosures Practice in Indonesian Chemical Industries : A Qualitative Content Analysis Study
}

\section{Warman Berkat Laoli ${ }^{*}$, Arthik Davianti²}

1,2 The Accounting Study Program at the Satya Wacana Christian University Faculty of Economics and Social Sciences

\section{A R T I C L E I N F O}

Article history:

Received 19 August 2019 Received in revised form 16 September 2019

Accepted 15 October 2019

Available online 29

November 2019

Keywords:

Health and safety,

prevention, implementation, handling.

\section{A B S T R A C T}

This study aims to determine the disclosure for occupational health and safety, as presented in GRI Standard-based CSR. A qualitative approach with content analysis was applied in the study. Content analysis is an analysis based on narrative according to certain criteria which classified through keywords and referred to as disclosure groups. The study focused on companies listed in Indonesia, in the chemical sector. The content analysis examined eleven companies. The results showed that based on the disclosures, all companies had implemented health and safety. Further, it also suggested that the disclosures were not necessary for accordance with GRI Standard.

\footnotetext{
* Corresponding author.

E-mail addresses: arthik.davianti@uksw.edu (Warman Berkat Laoli)
} 


\section{Introduction}

The company carries out operational activities to achieve the objectives of the company. Companies that focus on gaining profits will try optimally to get big profits. Large profits can be received by the company by maximally controlling the operational activities carried out by the company. From the company's operational activities, it can have environmental and social impacts, both positive and negative impacts. Positive impacts can lead to things that are beneficial to the environment and socially. While negative impacts can cause harm to the environment and socially. For companies, it is a challenge to reduce the possibility of negative impacts from operational activities carried out by the company. Therefore, to reduce the negative impact, companies must pay attention to the environment and social environment around the company.

In response to this, companies are encouraged to carry out social and environmental responsibility activities. These social and environmental responsibility activities can be carried out in the activities of Corporate Social Responsibility (CSR). According to Harmoni \& Andriyani (2008) CSR emphasizes that companies must develop ethical and sustainable business practices economically, socially, and environmentally. Therefore CSR is an action carried out by the company as a sense of corporate responsibility towards the society and the environment around the company. One CSR program that can be said to have a fairly high level of importance within the company is about employee health and safety. Karywan is one of the stakeholders in the company. Therefore the level of health and safety of employees is important to be one of the top priorities. The case study of this study focuses on the chemical industry listed on the Indonesia Stock Exchange (IDX).

The selection of the chemical industry listed on the IDX as the object of research was based on events that took place in the city of Cilegon about the explosion that occurred at PT Dover Chemical, resulting in one employee leaving the world and three others experiencing burns and two employees experiencing shortness of breath due to inhalation chemical gas (Berita Satu, 20016). The labor investigator at the Cilegon Manpower Office explained that the accident occurred during the loading of liquid chemicals from chemical tanks to tanker trucks. The explosion at PT Dover Chemical in the city of Cilegon proved that chemistry is one of the factors that can threaten the health and safety of employees. Chemical industry company employees will often work with chemicals. Thus the level of danger caused by chemicals is higher when compared to other industries.

Previous research related to CSR has been done. Namely, research conducted by Maygarindra \& Maghviroh (2012) found that the company did not disclose a number of items in each standard in detail in the sustainability report but from all aspects reported in the outline. Other research by Widenta (2012) found only part of the standard aspects of the Global Reporting Initiative (GRI) that have been used in implementing corporate CSR. Further research conducted by Sari (2014) found that all performance indicators on the GRI G 3.1 standard were disclosed, with average disclosures exceeding $75 \%$. although still not detailed.

The problem examined in this study is the occupational health and safety of employees in the corporate environment which is one of the important points in implementing CSR in companies that have various aspects of implementation that can be followed, especially based on the GRI Standard. Based on the research problem, the question in this study is how the disclosure of CSR activities that have been compiled by the company in accordance with the 2016 GRI Standard focusing on Occupational Health and Safety standards is? The purpose and benefit of this research are to analyze the CSR that has been made by the company focusing on occupational health and safety so that it will provide benefits to employees in the form of health and safety guarantees at work. Research using the GRI 2016 standard will show how disclosures in CSR on occupational health and safety are compiled by the company. If the company uses the GRI 2016 standard as a guideline for preparing CSR reports, then the disclosure of CSR will be well organized and will guarantee the health and safety of work for the parties related to the company.

\section{Methods}

This study uses a qualitative descriptive method with secondary data sources. Qualitative descriptive research forms describe the facts or circumstances of CSR disclosure carried out by the company. In this study, CSR reports will be data for analysis. Data collection for this research is done by utilizing data that has been provided by the company on the company's web or from a trusted website that provides data on the sustainability report of chemical industry companies.

The population in this study is a chemical industry company registered on the Indonesian stock exchange. The number of chemical industry companies listed on the Indonesian stock exchange is as many as eleven companies. Because there are not too many companies engaged in the chemical industry, the 
sample that will be used for this study is the total number of these companies. The list of chemical industry companies as samples in this study is as follows.

Table 1. List of Chemical Industry Sector Companies Listed on the Indonesia Stock Exchange

\begin{tabular}{clc}
\hline No. & \multicolumn{1}{c}{ Company Name } & Company Code \\
\hline & Aneka Gas Industri Tbk. & AGII \\
& Barito Pasific Tbk. & BRTP \\
& Budi Starch \& Sweetener Tbk. d.h Budi Acid Jaya Tbk. & BUDI \\
& Duta Pertiwi Nusantara Tbk. & DPNS \\
& Ekadharma International Tbk. & EKAD \\
& Eterindo Wahanatama Tbk. & ETWA \\
& Intan Wijaya International Tbk. & INCI \\
& Emdeki Utama Tbk. & MDK \\
& Indo Acitama Tbk. d.h Saraha Nugraha Tbk. & SRSN \\
0 & Chandra Asri Petrochemical Tbk. & TPIA \\
& Unggul Indah Cahaya Tbk. & UNIC
\end{tabular}

Source: (Saham OK) The name of the company will be addressed by the company stock code.

\section{Analysis Techniques}

The analysis technique used in this study uses qualitative content analysis. According to Mayring (2000), Qualitative content analysis is an empirical, methodological approach to the controlled analysis of text in the context of communication by following the content analysis rules and steps. The workings or logic of this analysis, according to Sartika (2014) i.e., this analysis starts using certain categories, then classifies data based on criteria and analyzes the data. The stages of the content analysis process in this study were adapted from Eriyanto (2011) are as follows:

There are six steps in the content analysis applied in this study. Explanation step by step in the content analysis process will be explained as follows.

Stage One: Formulate the Objectives of Analysis The purpose of analysts is seen from the research objectives, namely analyzing CSR that has been compiled by the company focusing on occupational health and safety. Analysis using content analysis aims to see the contents of CSR reports that have been made by the company focused on occupational health and safety.

Second Stage: Conceptualization and Operationalization In this study, the concept used consisted of two main concepts, namely the Law on Occupational Health and Safety, and the second concept was the GRI standard. There are two occupational health and safety laws, namely Undang-undang No. 23 Tahun 1992 Tentang Kesehatan Kerja dan Undang-undang No. 1 Tahun 1970 Tentang Keselamatan Kerja. Both laws on occupational health and safety contain information about the appropriate treatment at work.

The GRI concept used is the GRI 403 specific topic standard on occupational health and safety. Information contained in specific topic standards GRI 403 is a workplace health and safety disclosure standard that must be reported by the company. Both of these concepts contain disclosure groups as a standard in making disclosures about occupational health and safety. The disclosure groups are Health and Safety, Prevention, Implementation, and Accident Management. Details of these two concepts are described in Table 2 and Table 3.

Table 2. Undang No. 23 Tahun 1992 Tentang Kesehatan Kerja dan Undang-undang No. 1 Tahun 1970 Tentang Keselamatan Kerja

\begin{tabular}{cl}
\hline No & \\
\hline 1 & Occupational health services \\
2 & Prevention of occupational diseases \\
3 & Prevent and reduce accidents \\
4 & Prevent, reduce and extinguish fires \\
5 & Prevent and reduce the danger of blasting \\
6 & Provide a chance or a way to save yourself during a fire or other dangerous event \\
7 & Provide help to an accident \\
8 & Provide self-protection tools to workers \\
9 & Prevent and control the rise or spread of temperature, humidity, dust, dirt, smoke, steam, gas,
\end{tabular}


10 Prevent and control the emergence of diseases due to work both physically and psychologically, poisoning, infection, and transmission

11 Obtain sufficient and appropriate information

12 Organize temperatures and good humid air

13 Carry out sufficient air refreshment

14 Maintain cleanliness, health, and order

15 Obtaining harmony between labor, work tools, environment, ways and processes of work

16 Secure and facilitate the transportation of people, animals, plants or goods

17 Securing and maintaining all types of buildings

18 Secure and expedite loading and unloading work, treatment and storage of goods

19 Prevent exposure to dangerous electricity

20 Adjusting and perfecting security at work where the danger of accidents becomes higher.

Table 3 Global Reporting Initiative About Occupational Health and Safety

\begin{tabular}{cc}
\hline No & \multicolumn{1}{c}{ Requirements } \\
\hline 1 & At the level where the combined official management-worker committee for health and safety \\
usually operates within the organization.
\end{tabular}

Third Stage: Coding Sheet In this study, coding sheets are made in the form of Microsoft Office Excel. The contents of the coding sheet are all reporting requirements based on GRI and the Law on occupational health and safety found in table 2 and table 3 in the second stage. All reporting requirements will be analyzed based on keywords that include protection and security equipment, health facilities, accidents, committees, and work environment.

Fourth Stage: Population and Samples The population for this study is the chemical industry companies listed on the IDX. The number of chemical industry companies listed on the IDX is eleven companies. The sample that will be used in this study are all chemical industry companies listed on the IDX. The list of names of companies listed on the IDX has been compiled in Table 1.

Fifth Stage: Coding Process Proses coding dilakukan dengan memeriksa seluruh kata kunci yang terdapat pada lembar coding dengan laporan CSR yang telah dibuat oleh perusahaan. Proses coding dilakukan dengan menelusuri kata kunci ke dalalm laporan keuangan perusahaan. Kata kunci yang digunakan dalam proses coding adalah peralatan pelindung dan pengamanan, fasilitas kesehatan, kecelakaan, Komite, dan lingkungan kerja.

Stage Six: Data Input and Analysis In the last stage, the results of the coding process will be input and analyzed in the data. The analysis in question is to see how compatible CSR disclosures are carried out by the company.

\section{Result and Discussion}

The analysis process is carried out by analyzing all reporting requirements in Tables 2 and 3, which have been grouped into four groups, namely Health and Safety, Prevention, Implementation, and Accident Management. Analysis of the four disclosure groups was helped by using keywords that were explained in the fourth stage of the analysis technique. The results of the analysis and discussion of the four disclosure groups are presented below. 


\section{Health and Safety}

Disclosures relating to occupational health and safety have been presented in the CSR of most observation companies in this study. The state of the employee has become an important concern for the company, which can be seen from the disclosure of all policies implemented by the company relating to occupational health and safety. Based on the analysis of disclosures presented by the companies concerning CSR, the results showed disclosures on the provision of polyclinics for employees, provision of health insurance and health benefits, as well as periodic employee health checks and provision of safety equipment to employees. The following are excerpts of disclosures regarding health and safety presented in the company's CSR.

Perusahaan memberikan tunjangan kesehaan serta fasilitas klinik kesehatan yang bukan selama 24 jam dengan seluruh biaya pemeriksaan dan obat-obatan ditanggung oleh perusahaan. (BUDI Laporan Tahunan Tahun 2017 Hal. 71) Fasilitas klinik untuk karyawan (DPNS Laporan Tahunan Tahun 2017 p 65)

Mengikutsertakan karyawan ke dalam program asuransi kesehatan dan pensiun melalui Badan Penyelenggara Jaminan Sosial (BPJS) Kesehatan dan Tenaga Kerja. (Laporan Tahunan Tahun $p$ 89)

Perseroan juga secara rutin memberikan fasilitas pemeriksaan kesehatan bagi seluruh karyawanny dan juga mengadakan kerjasama dengan beberapa rumah sakit di sekitar tempat Perseroan beroperasi, untuk menjamin kesehatan dan penanganan kondisi darurat bagi karyawan dan keluarga. (Laporan Tahunan Tahun 2017 p 110)

Menyediakan Alat Pelindung Diri (APD) untuk karyawan yang bekerja di tempat yang berisiko (DPNS Laporan Tahunan Tahun 2017 p 65)

Based on the analysis, evidence revealed that the company CSR activities, namely the existence of disclosures from the beginning of the observation period to the end of the year of the observation period which is from 2015 to 2017 is inconsistent. The results also showed that in BRTP and INCI companies. The disclosure of BRTP CSR in the annual financial statements for 2015 to 2016 has no disclosures related to occupational health and safety, but in CSR in the annual financial statements for 2017, there are disclosures related to occupational health and safety. The following is a disclosure quote presented by BRTP.

Pedoman K3 yang berlaku di CAP disusun dengan tajuk "Life Saving Rules" yang menekankan bahwa keselamatan kerja dapat diwujudkan melalui kontribusi, kewaspadaan dan kepedulian seluruh karyawan. (BRTP lapoortan Tahunan Tahun 2017 p 80)

Perusahaan melakukan sosialisasi Dalam rangka melaksanakan pembinaan dan pelatihan bertajuk "Program Penyegaran Tahunan" yang bertujuan untuk meningkatkan kesadaran pencegahan kecelakaan kerja. (BRTP lapoortan Tahunan Tahun 2017 p 80)

The disclosure pattern similar to Barito Pacific Tbk is also found in CSR of Intan Wijaya International Tbk (INCI). Disclosures contained in the Intan Wijaya International Tbk CSR are the opposite of those found in Barito Pacific Tbk. In 2015 the company had an occupational health and safety account, but in the following year, it was 2016 and 2017 the disclosure was not found anymore. The following is a quote from INCI

Perseroan menyediakan poliklinik dan tenaga medis untuk memantau dan memelihara kesehatan karyawan dan keluarganya serta masyarakat sekitar (INCI Laporan Tahunan Tahun 2015 p 30)

Disclosures related to the provision of polyclinics for employees, the provision of health insurance and health benefits, and periodic employee health checks and the provision of safety equipment to employees contained in the corporate CSR disclosures showed that the health and safety of employees are very much noticed by every company. This can be proven by the results of the analysis which found that all the companies that were the case study studies had disclosures about health and safety

Thus, it can be concluded that the health and safety disclosure group in the CSR of most companies is in accordance with regulations Undang No. 23 Tahun 1992 Tentang Kesehatan Kerja dan Undangundang No. 1 Tahun 1970 Tentang Keselamatan Kerja and GRI. This is evidenced by ten companies that have health and safety disclosures, and only one company, namely the TPIA, which has no health and safety-related disclosures. Of the ten companies that have disclosures about health and safety, there are two companies that are inconsistent in making disclosures. The company is BRTP and INCI. The disclosure 
of the two companies is in accordance with the GRI and applicable regulations, but the disclosure has inconsistencies in term of the presentation of disclosures about health and safety in the corporate CSR disclosures every year of the research observation period.

Prevention

Based on the results of the disclosure analysis related to prevention listed in the company's CSR, it includes socialization of K3, using posters, maintenance of equipment and work environment, hygiene policy, and the committee that oversees the work process of employees. The results of the analysis show a small portion of the whole company that has prevention-related disclosures. Companies that have disclosures are AGII, MDK and TPIA.

AGII and MDKI companies have similarities in two points of disclosure, namely the interests of the work environment and the dangers of work. The principal disclosure of the first AGII Company is to maintain all facilities and infrastructure on a scheduled basis. A similar thing is also done by MDKI companies by building a healthy and safe environment. The difference between the two companies is that MDKI disclosures are concise and are not accompanied by details of what activities they do to achieve a healthy and safe environment. The following are disclosure quotes from these two companies.

Perawatan semua sarana dan prasarana yang dimiliki Perusahaan dilakukan secara terjadwal. Perusahaan juga menerapkan kebijakan yang sangat ketat di lingkungan pabrik seperti adanya larangan keras merokok di dalam pabrik. (AGII Laporan Tahunan Tahun 2017 pp 219 \& 220)

Perusahaan selalu mensosialisasikan Program K3 untuk meningkatkan kepedulian terhadap Keselamatan, Kesehatan Kerja \& Lingkungan dimanapun Perusahaan beroperasi dan menerapkan Sistem Manajemen Keselamatan, Kesehatan Kerja \& Lingkungan dan senantiasa memperbaikinya ( AGII Laporan Tahunan Tahun 2017 p 220)

Perseroan juga berupaya membangun lingkungan kerja yang sehat, aman, dan nyaman guna meningkatkan produktivitas kinerja karyawan secara optimal. ( MDKI Laporan Tahunan Tahun 2017 p 89)

The second point of the disclosure relates to the dangers of work; AGII companies install posters and signs for each room. Further, MDKI has a supervisory committee and implements a system to identify potential hazards and mitigate them. The following are disclosures from the two companies.

Pemasangan poster dan rambu tentang HSE akan diletakkan pada setiap bagian dan ruangan. Selain itu akan ada poster yang terkait dengan hasil investigasi atau laporan kecelakaan sebagai bentuk peringatan bagi pekerja agar tidak mengulangi hal yang sama. (AGII Laporan Tahunan Tahun 2017 p 221)

Adapun salah satu bentuk tanggung jawab Perseroan ialah senantiasa berusaha mengantisipasi risiko kegagalan kerja, dengan di bawah pengawasan Panitia Pembina Keselamatan dan Kesehatan Kerja (P2K3). Departemen ini melakukan sosialisasi dan pengawasan secara periodik. (MDKI Laporan Tahunan Tahun 2017 p 89)

Perseroan juga menerapkan Sistem Manajemen Keselamatan dan Kesehatan Kerja (K3), yakni dengan melakukan identifikasi potensi bahaya, menilai tingkat risiko, serta menetapkan upaya pengendalian melalui program-program yang telah dirancang. (MDKI Laporan Tahunan Tahun 2017 p 89)

Based on the two main disclosures from the two companies, when viewed from the principal disclosure of the work environment, the AGII company has more detailed disclosures. However, the disclosure of the dangers of MDKI companies' work can be considered better with more disclosures. TPIA also has disclosure regarding prevention, but the standards or rules used by TPIA companies are different from those used by AGII and MDKI companies. In implementing occupational health and safety, the TPIA company is guided by Life Saving Rules as Golden Rules, namely a kitap that has rules on workplace safety. Besides this, the TPIA company also has a job risk assessment system based on Hazard Identification Risk Assessment and Determine Control (HIRADC) and Job Hazard Analysis. The following is a quote related to the prevention of TPIA companies. 
Dalam pelaksanaan K3 di lingkungan Perusahaan, Perseroan berpedoman pada Life Saving Rules as Golden Rules, sebuah kitab keselamatan kerja yang mengatur segala bentuk aturan keselamatan yang harus ditaati semua orang di dalam Perseroan, berikut sanksi atas pelanggarannya. (TPIA Laporan Tahunan Tahun 2017 p 172)

Implementasi program Behavior-based Safety (BBS) untuk membangun perilaku mencegah kecelakaan di antara para karyawan. (TPIA Laporan Tahunan Tahun 2017 p 173). Pelaksanaan Program Penyegaran Tahunan, sebuah program pelatihan dan pembinaan untuk mengurangi angka kecelakaan kerja. (TPIA Laporan Tahunan Tahun 2017 p 173)

Penilaian risiko pada kegiatan-kegiatan Perseroan dan upaya pencegahannya berdasarkkan prosedur HIRADC (Hazard Identification Risk Assessment and Determine Control) dan Job Hazard Analysis. (TPIA Laporan Tahunan Tahun 2017 p 173)

The rules in life-saving rules and golden rules are stated in other documents found on the official website of the TPIA company. In the regulation shows the form of actions that must be carried out and not carried out by all employees. These disclosures about life-saving rules and gold rules show that the company has prepared all the proper procedures to prevent accidents from occurring when doing work. Thus it can be concluded that there are only three companies from eleven companies that have prevention disclosure groups in accordance with regulations Undang No. 23 Tahun 1992 Tentang Kesehatan Kerja dan Undang-undang No. 1 Tahun 1970 Tentang Keselamatan Kerja and GRI. Based on the results of the analysis, it is known that the disclosure of each company has several similarities with each other and all disclosures made by the company are in the GRI and the applicable laws and regulations.

\section{Implementation}

Disclosure of implementation is related to the prevention process that has been carried out by the company. From the results of the principal analysis of disclosures contained in the CSR of the entire company is the provision of protective and security equipment, counseling, monitoring, fire extinguishers, as well as employee training. Based on the results of the analysis, six companies are known to have disclosures about protective and security equipment. The six companies are AGII, DPNS, ETWA, UNIC, BUDI, and INCI.

The six companies have the same core disclosure that is related to Protective Equipment and security. AGII and BUDI companies have more detailed disclosures in making disclosures. AGII and BUDI in their CSR explained what types of equipment were given to their employees. Whereas DPNS, ETWA, UNIC and INCI companies are more on brief expositions of companies providing protective equipment to employees, but do not mention any items that are intended as protective equipment. The following are some disclosure quotes from these four companies:

Setiap karyawan yang berada di lingkungan pabrik harus menggunakan peralatan pelindung tubuh seperti kacamata pelindung, helm, sepatu dan sarung tangan pelindung. (AGII Laporan Tahunan Tahun 2017 pp 219 - 220)

Menyediakan Alat Pelindung Diri (APD) untuk karyawan yang bekerja di tempat yang berisiko (DPNS Laporan Tahunan Tahun 2017 p 65)

Penyediaan sarana dan prasarana K3 di pabrik PT AG seperti fasilitas pemadam kebakaran serta Alat Pelindung Diri (APD) dan melakukan perawatan rutin dan melakukan tes kehandalan untuk menjamin bahwa semua sarana dan prasarana K3 tersebut dapat digunakan bilamana dibutuhkan. (ETWA Laporan Tahunan Tahun 2017 p 80)

Mengirimkan karyawannya untuk mengikuti pelatihan dan worshop di bidang K3 agar memperoleh ketrampilan yang memadai, di samping itu perseroan juga memfasilitasi penyediaan peralatanperalatan K3 guna mendukung program K3 tersebut. (UNIC Laporan Tahunan Tahun 2017 p 109)

Terdapat safety helmet, safety shoes, ear plug, full body hardness, sarung tangan, masker, penutup rambut, kaca mata pelindung, dan lainnya disediakan oleh Perusahaan untuk memberikan perlindungan kerja bagi karyawan. (BUDI Laporan Tahunan Tahun 2017 p 71)

Sarana, prasarana, dan keamanan kerja harus terjaga dengan baik. (INCI Laporan Tahunan Tahun 2017 p 47)

Subsequent disclosures related to counseling, monitoring, fire extinguishers, and employee training were found in three companies, namely DPNS, ETWA, and UNIC. The disclosure patterns of the three companies are similar to each other. The DPNS company, in its CSR, revealed that the company carried out counseling on health and safety conditions. The same thing is also done by ETWA; they conducted several 
socializations and trainings for their employees. In addition, DPNS and ETWA also revealed that the company always monitors the tubes inside the company and conducts a safety patrol every month to monitor health and safety conditions. Furthermore, the ETWA company also prepares fire fighting equipment. The UNIC company, the disclosure, only stated that company employees would be sent to attend training related to occupational health and safety. The following is an excerpt from every company.

Pemantauan secara berkala terhadap tabung (DPNS Laporan Tahunan $p$ 65) Melakukan Safety Patroll setiap bulan untuk memantau kondisi K3 di pabrik dan dilaporkan ke dinas Ketenaga kerjaan melalui laporan P2K3. (ETWA Laporan Tahunan Tahun 2017 p 80) Penyuluhan pentingnya K3 pada karyawan (DPNS Laporan Tahunan $p$ 65)

Mengirimkan karyawannya untuk mengikuti pelatihan dan worshop di bidang K3 agar memperoleh ketrampilan yang memadai, di samping itu Perseroan juga memfasilitasi penyediaan peralatan-peralatan K3 guna mendukung program K3 tersebut.(UNIC Laporan Tahunan Tahun 2017 p 109)

Penyediaan fasilitas pemadam kebakaran serta Alat Pelindung Diri (APD) dan melakukan perawatan rutin dan melakukan tes kehandalan untuk menjamin bahwa semua sarana dan prasarana K3 tersebut dapat digunakan bilamana dibutuhkan. (ETWA Laporan Tahunan Tahun 2017 p 82)

Disclosures about protective and security equipment, counseling, monitoring, fire extinguishers, and training of employees in all companies can be considered good. This is evidenced by the content of each company's disclosure, which reflects the occurrence of occupational health and safety. Thus it can be concluded that disclosures that are in accordance with the regulations of Law No. 23 of 1992 concerning Occupational Health and Law No. 1 of 1970 concerning Work Safety and GRI in the implementation disclosure group owned only by six companies. All disclosures from the six companies are in accordance with GRI and applicable regulations. In the disclosure group, the main thing that was almost revealed by the six companies was about providing protective equipment to employees. This is in accordance with that found in legislation and GRI.

\section{Accident Handling}

Disclosures relating to accidents are only found in SRSN and TPIA companies. The following is a disclosure quote for the SRSN company.

Terdapat Panitia Pembina Keselamatan dan Kesehatan Kerja serta dibuat risk assesmet guna pencegahan terjadinya resiko kecelakaan kerja dan penyakit akibat kerja. (SRSN Laporan Tahunan Tahun 2017 p 59)

Based on the results of the analysis only found one company that revealed about workplace accidents. SRSN companies do not have disclosures in prevention groups or implementations. However, in CSR, the company mentioned the number of accidents that occurred at the company. This shows that the SRSN company does not focus on occupational health and safety, but it cannot be said that SRSN companies do not have policies or standards regarding occupational health and safety due to company disclosures stating that there were no work accidents in 2016 and 2017. Subsequent disclosures to TPIA companies that have disclosures about the number of accidents occurring in 2016 and 2017. The following are disclosures of TPIA company disclosures.

Pada tahun 2016, tidak terjadi kecelakaan yang menyebabkan Lost Time Accident (LTA). Bahkan, Perseroan berhasil mencapai 10 Juta Jam Kerja tanpa LTA pada tanggal 1 September 2016. (TPIA Laporan Tahunan Tahun 2016 p. 176)

Terjadi kecelakaan yang tidak menimbulkan korban jiwa, hanya korban luka (TPIA Laporan Tahunan Tahun 2017 p 173)

In the prevention disclosure group, the TPIA company has revealed that companies use life-saving rules and golden rules as workplace health and safety standards. Based on the results of observations in 2016, the company did not experience problems related to work accidents. This shows that the standard used has been applied properly and correctly.

Related disclosures in 2017 showed a performance that was the opposite of what had happened in 2016 regarding health and overall work. In 2016 there was no incident related to work accidents, but in 2017 there was an accident even though there were no casualties but caused injuries. This incident shows 
that the application of occupational health and safety standards used by the company is good enough to maintain the safety of the souls of employees. Based on observations regarding this incident, the company did not have further disclosures regarding the handling of accidents that occur.

Thus it can be concluded that there is no disclosure of groups dealing with accidents in CSR throughout the company with compliance with regulations Undang No. 23 Tahun 1992 Tentang Kesehatan Kerja dan Undang-undang No. 1 Tahun 1970 Tentang Keselamatan Kerja and GRI. In the disclosure group handling accidents only found reports from several about the number of accidents that occurred in the company. For handling or follow-up of accidents that occur, the company has no disclosures related to these matters.

\section{Conclusion}

The problem in this study is how disclosure in the company's CSR related to employee health and safety is based on the 2016 GRI standard. The GRI standard is a guide that can be used as a guideline for implementing company policies related to occupational health and safety. This research concluded on four disclosure points, which included Health and Safety, Prevention, Implementation, and Accident Management. Of the four disclosure groups, the Health and Safety group is the group that has the most disclosures. However, in the Health and Safety disclosure group, there is also an inconsistent pattern of disclosures in terms of presentation on corporate CSR in the period of the year of research observation. The overall occupational health and safety disclosure group have detailed disclosures, but there are only a few public disclosures.

Furthermore, the principle of prevention is only owned by three companies. Disclosures carried out by each company have almost the same meaning in some disclosure items. Like the MDKI conversation which states that the company will build a healthy and safe work environment, also delivered by AGII, who has an environmental hygiene policy. Both of these disclosures have the same core disclosure to maintain a safe and healthy work environment. The next disclosure group is the Implementation group, which has quite a lot of disclosures done by each company, particularly there were six companies that have disclosures. In this disclosure group, the main thing that exists is about providing protective equipment to employees. But a number of companies besides providing protective equipment also implement several policies such as monitoring and checking the condition of the factory as implemented by ETWA and DPNS. The last disclosure group is the Accident Handling group. Disclosures concerning the corporate CSR practices related to the Accident Handling disclosure group have results that have the least compatibility with GRI and the applicable laws and regulations. In CSR, some companies only present the number of accidents that have occurred but follow-up or handling after accidents have not been disclosed by the company.

Based on the results of the overall analysis, the contents of the disclosure of the entire company are good, although not yet detailed. The detailed disclosure function can give an idea that the company gives great attention to occupational health and safety. Some companies in the disclosure group have detailed disclosures and good applications so that the level of accidents can be minimized. This study found several companies whose disclosures about occupational health and safety were not optimal or not detailed. For this reason, with this research, it is expected that the company will be able to optimize further its disclosure regarding occupational health and safety In this study also has limitations, namely corporate CSR which as a whole is in the annual financial report and in some companies there is no annual financial report. This causes this research cannot get the data needed in all observation periods. For further research, it is expected to choose a longer research period so that more data is obtained to support data processing that will be more maximal in decision making. In addition to the selection of the research period, it is also expected that further research will carry out studies on other types of industries so that they can be a comparison of knowledge about disclosure of occupational health and safety..

\section{Reference}

Arfamaini, R. (2016). Pelaporan corporate social responsibility (CSR) dengan menggunakan global reporting initiative (GRI). E-Jurnal Manajemen Kinerja E-ISSN: 2407-7305, VOL 2, Nomor 2 Agustus 2016.

Berita Satu. (20016, Februari 18). Pabrik Kimia di Cilegon Meledak, Satu Tewas. Retrieved from www.beritasatu.com: https://www.beritasatu.com/nasional/350150/pabrik-kimia-di-cilegonmeledak-satu-tewas. 
Cheng, M., \& Christiawan, Y. J. (2011). Pengaruh pengungkapan corporate social responsibility terhadap abnormal return. JURNAL AKUNTANSI DAN KEUANGAN, VOL. 13, NO. 1, MEI 2011, 24-36.

Daud, R. M., \& Amri, A. (2008). Pengaruh intelectual capital dan corporate social responsibility terhadap kinerja perusahaan (studi empiris pada perusahaan manufaktur di bursa efek indonesia). JURNAL TELAAH \& RISET AKUNTANSI Vol. 1, No. 2., 213-231.

Eriyanto. (2011). Analisis isi pengantar metodologi untuk penelitian ilmu komunikasi dan ilmu-ilmu sosial lainnya. Kencana prenda media group.

Fontaine, C., Haarman, A., \& Schmid, S. (2006). The Stakeholder Theory. 3.

Friedman, A. L., \& Miles, S. (2006). Stakeholders Theory and Practice. Oxford University Press, 1.

Global Reporting Initiative. (2018, Juni 29). Global Reporting Initiative. Retrieved from www.globalreporting.org: gri/Pages/default.aspx https://www.globalreporting.org/information/about-

Harmoni, A., \& Andriyani, A. (2008). Pengungkapan corporate social responsibility (CSR) pada official website perusahaan studi pada Pt.Unilever Tbk. Seminar Ilmiah Nasional Komputer dan Sistem Intelijen (KOMMIT 2008) ISSN : 1411-6286, 475-483.

Maygarindra, P. B., \& Maghviroh, R. E. (2012). Analisis alokasi dana corporate social responsibility serta pelaporan sustainability report berdasarkan global reporting initiative (GRI G3) di PT. Pembangkitan jawa bali. The Indonesian Accounting Review Volume 2, No. 2, July 2012,, 173 - 184.

Mayring, P. (2000). Qualitative content analysis. Forum Qualitative Sozialforschung / Forum: Qualitative Social.

Purwanto, A. (2011). Pengaruh tipe industri, ukuran perusahaan, profitabilitas, terhadap corporate social responsibility. Jurnal Akuntansi \& Auditing Volume 8/No. 1/November 2011:, 1-94.

Republik Indonesia. (1970, Januari 12). JDIH. Retrieved from http://www.dpr.go.id: http://www.dpr.go.id/idih/index/id/641.

Republik Indonesia. (1992, September 17). JDIH. Retrieved from http://www.dpr.go.id: http://www.dpr.go.id/idih/index/id/639.

Saham OK. (n.d.). www.sahamok.com/emiten/sektor-industri-dasar-dan-kimia/sub-sektor-kimia/. Retrieved from www.sahamok.com: https://www.sahamok.com/emiten/sektor-industri-dasardan-kimia/sub-sektor-kimia/.

Sari, N. (2014). Analisis pengungkapan corporate social responsibility berdasarkan global reporting initiative (GRI): studi kasus perusahaan tambang batu bara bukit asam (persero) tbk dan timah (persero) tbk. BINUS BUSINESS REVIEW Vol. 5 No. 2 November 2014:, 527-536.

Sartika, E. (2014). Analisis isi kualitatif pesan moral dalam film berjudul "kita versus korupsi". E-Jurnal Ilmu Komunikasi Volume 2, Nomor 2, 2014, ISSN 0000-0000„, 63-77.

Widenta, Y. P. (2012). Analisis implementasi corporate social responsibility pt. indosat tbk. tahun 20072011 berdasarkan global reporting initiative. Jurnal Ilmiah Mahasiswa FEB Vol 1, No 1: Semester Ganjil 2012/2013.

Wulolo, C. F., \& Rahmawati, I. P. (2017). Analisis pengungkapan corporate social responsibility berdasarkan global reporting initiative G4. Jurnal Organanisasi dan Manajemen, 53-60. 